DOI:10.30842/ielcp230690152372

Richard J. A. Talbert

(University of North Carolina, Chapel Hill, USA)

\title{
A LOST SUNDIAL FOUND, AND THE ROLE OF THE HOUR IN ROMAN DAILY LIFE
}

The first of two sections reassesses the no longer lost "Aquileia" portable sundial disc. The networks of lines on either side are now reckoned to be drawn for latitudes 36 and 38, so that in the former instance RO is more likely to signify $\mathbf{R O}(\mathrm{DOS})$ than $\mathbf{R O}(\mathrm{MA})$. In the latter instance, close inspection of photographs now indicates that neither RA nor a single A should be read, and SM(YRNA) is tentatively proposed. The second section argues, with brief illustration, that preoccupation with hours merits overdue recognition as beyond doubt a formative, universal feature of Roman community life, more so than in any other society of the ancient Mediterranean, Egypt or the Near East. Investigation is urged of how, why and when this raised level of time consciousness developed, what impact it made, and why and when it eventually faded.

Key words: Hour, Latitude, Romans, ancient; Smyrna, Sundial, Time Consciousness, Timekeeping

\section{Р. Дж. А. Талберт \\ (Университет Северной Каролины в Чапел-Хилл, США)}

\section{Находка утерянных солнечных часов и роль деления на часы в повседневной жизни Рима}

В первом из двух разделов статьи подробно рассматриваются диски портативных солнечных часов, подобных найденному в Аквилее в 1883 г. Сети линий на обеих сторонах диска считаются соответствующими 36 и 38 широтам, поэтому надпись RO скорее обозначает RO(DOS), а не RO(MA). Тщательное исследование фотографий обратной стороны позволяет прийти к выводу, что там невозможно идентифицировать ни RA, ни отдельного A, поэтому предварительно предлагается читать надпись как SM(YRNA).

Во втором разделе на нескольких примерах показано, что следует признать, что деление на часы стало важной универсальной чертой, ярко характеризующей общественную жизнь Рима в большей степени, чем любое другое общество древнего Средиземноморья, Египта или Ближнего Востока. Необходимо осмыслить, как, почему и когда возникло внимание к отслеживанию дневных часов, какое влияние оно оказало на жизнь в древнем Риме и почему перестало быть актуальным в Средние века.

Ключевые слова: час, широта, древние римляне, Смирна, солнечные часы, чувство времени, хронометрирование. 
This contribution has two related parts. The first focuses on a single sundial disc now rediscovered, and the second then proceeds to consider more broadly the keeping of time in Roman daily life ${ }^{1}$.

To recall lost ancient sundials while in St. Petersburg is especially appropriate, because the one acquired in Egypt by Constantin von Tischendorf in 1859 evidently came to the Hermitage Museum here at some later date (Talbert 2017: 29-34 with bibliography). It was said to have been retrieved from a necropolis at Memphis (near Cairo), and to judge by von Tischendorf's drawings it was well preserved. There are no photographs. Von Tischendorf claims to have taken care over the drawings, but he did not record any dimensions unfortunately [Fig. 1]. By now, both the disc and the shadow-caster have long been missing. That is a grave loss, not least because this example of a portable sundial - a type that needs to be suspended, and has geographical names and their latitudes listed on its disc's reverse - is matched (to date) by only one other with as many as 36 names, also in Greek ${ }^{2}$.

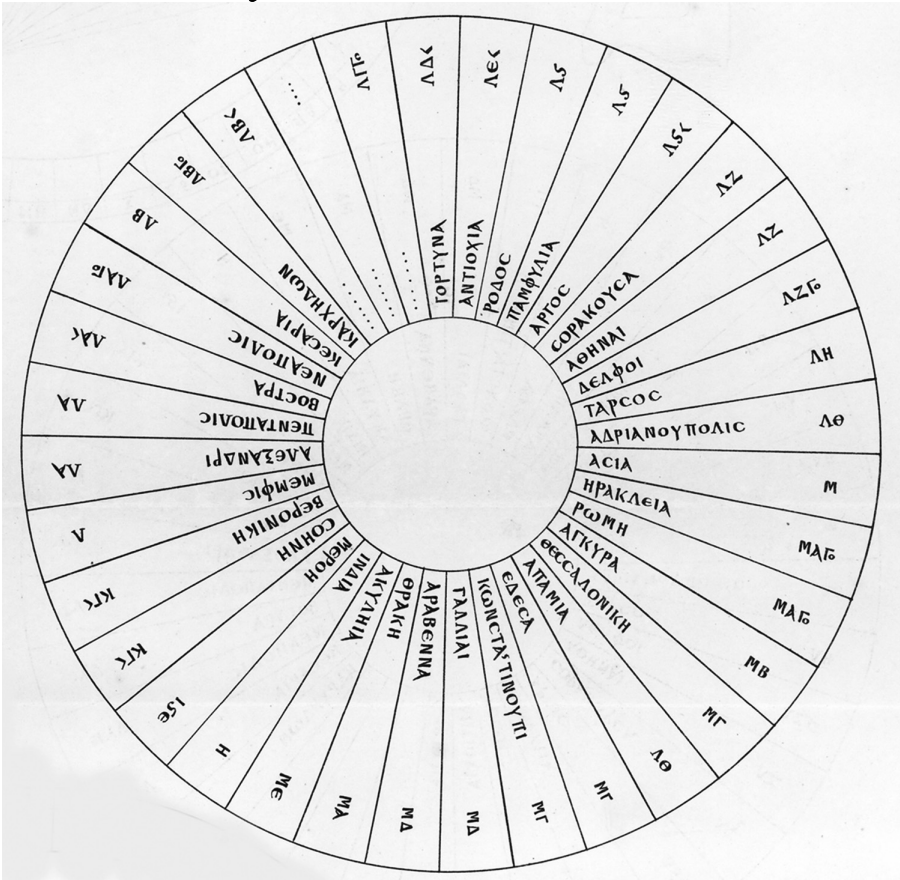

Fig. 1. Disc (reverse) of the "Memphis" portable sundial purchased by Constantin von Tischendorf in 1859, as drawn by him.

\footnotetext{
${ }^{1}$ My thanks to Caroline Kennedy and Olivia Zitkus (both University of North Carolina, Chapel Hill) for Fig. 7; to Gerald Kadish (Binghamton University, New York) for guidance on timekeeping in ancient Egypt and the Near East; and to Lindsay Holman (director, Ancient World Mapping Center) for assistance with preparation of the Figures.

${ }^{2}$ No. 15 "British Museum" in Talbert 2017: 99-103. This sundial lacks provenance and only became known when the Museum acquired it in 1997.
} 
Another, rarer type of portable sundial is the "pillbox." It is very small - its diameter comparable to that of a coin - and it stands on a surface rather than needing to be suspended (Talbert 2017: 1314). Sunrays passing through a small hole in the side fall onto a "hand" (as of a clock) inside, which in turn is set over a network of lines drawn to mark the hour [Fig. 2]. The simplest examples of this type have just one network of such lines - drawn, in other words, for a single latitude. The name of a place at about that latitude may, or may not, be stated above or beside the network ${ }^{3}$. Other examples of the type are more versatile, because they incorporate interchangeable discs with a range of networks inscribed on them for use at different latitudes, and with the name of a place or region at about the corresponding latitude stated alongside the network in each case. Once you know the approximate latitude of the location where you want to use such a sundial, you just insert the relevant disc and determine the hour from that. In principle there is no limit to the number of discs that might be produced for this type of portable sundial. The best preserved surviving example is one said to be a find from Aquileia, which has been in the Kunsthistorisches Museum, Vienna, since the eighteenth century. It was first published by Friedrich Kenner in $1883^{4}$. We have it with four discs each inscribed on both sides, but quite possibly there were more which have been lost ${ }^{5}$.

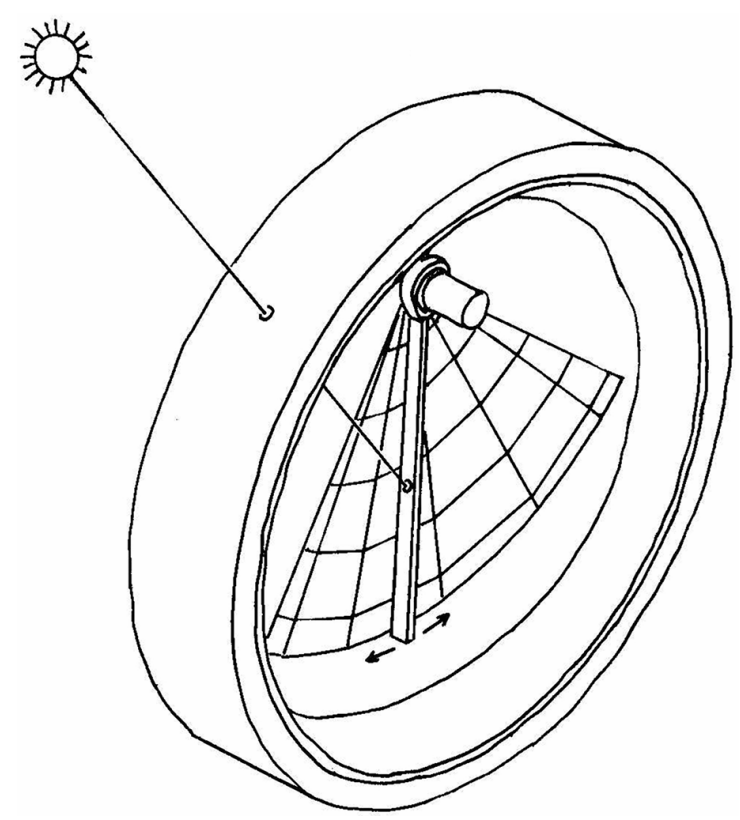

Fig. 2. Functioning of a "pillbox" sundial. Sketch by Paolo Auber reproduced from Talbert 2017: 13.

${ }^{3}$ For the latter, see Talbert 2017: 27-29.

${ }_{5}^{4}$ See Talbert 2017: 36-48 with bibliography.

${ }^{5}$ The four discs were fused to each other and to the bottom of the box until the Museum successfully separated them in 1957 (Talbert 2017: 38). 
When Kenner was visiting the Roman site at Aquileia, a local resident showed him one disc - diameter $3.1 \mathrm{~cm}$ - from what must have been another such "pillbox" portable sundial (Talbert 2017: 35-36). Kenner published this in 1880, with his drawings of both sides [FIG. 3]. Thereafter nothing further was heard of this disc, and right into the present century it has always been assumed lost, being noted thus in lists of known Greek and Roman portable sundials (so, too, in my own book Roman Portable Sundials: The Empire in Your Hand, published in 2017). Recently, however, this assumption has been proven false, I am happy to report.
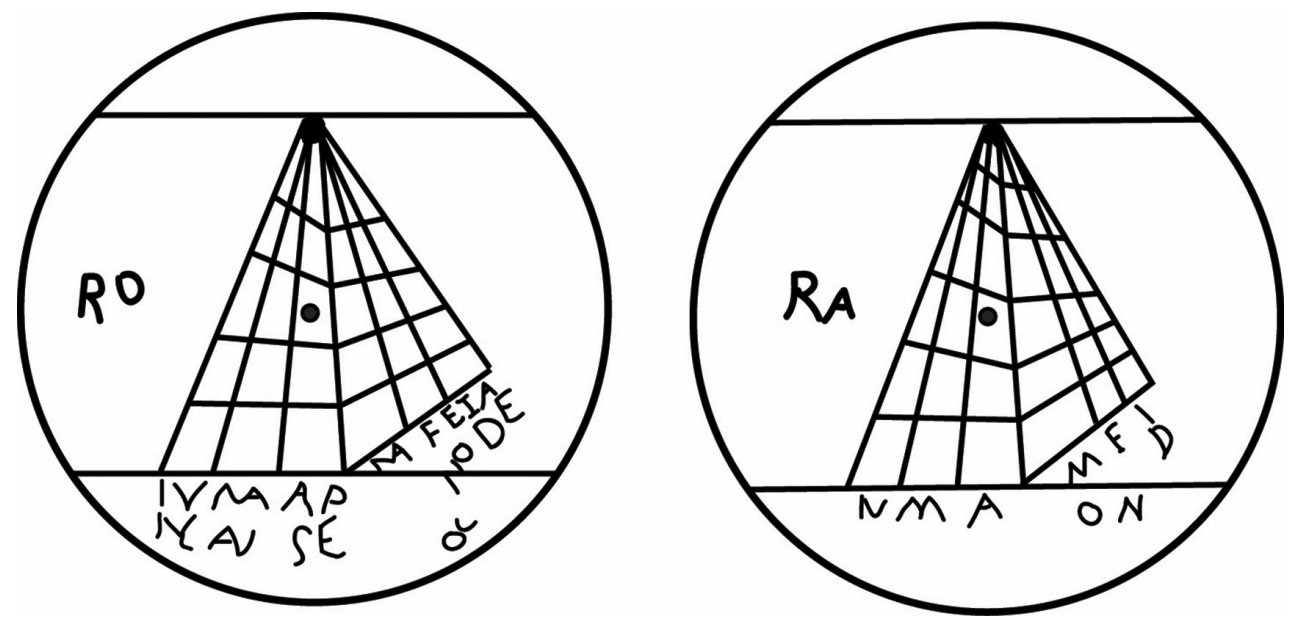

Fig. 3. "Aquileia" sundial disc drawn by Friedrich Kenner (1880) as copied by the Ancient World Mapping Center (Talbert 2017: 35).

First to draw attention to the refound disc, and to reassess it, was the engineer and avocational sundial expert Paolo Albèri-Auber. $\mathrm{He}$ recognized it (inv. 5423) in the collection of the Civici Musei di Trieste, Italy, his home-town as it happens. He published his reassessment in Gnomonica Italiana 2005, and subsequently summarized and reaffirmed his views in The Compendium 2018. To be frank, neither of these journals circulates widely. In consequence, Alexander Jones (Institute for the Study of the Ancient World, New York University) was evidently unaware of Albèri-Auber's 2005 article when he too recognized this disc in Trieste. He was visiting museums in Europe to select items for display in the Institute's exhibition Time and Cosmos in Greco-Roman Antiquity, which ran from October 2016 to April $2017^{6}$. Jones makes just a brief passing reference to his recognition of the no-longer-lost disc in his review of my book, published in the April 2018 issue of Classical Philology.

${ }^{6}$ However, the disc was not included in the exhibition. 
Albèri-Auber's six-page reassessment in 2005 calls for more extended attention. He advances two related claims, which he is able to base on photographs provided by the Trieste Museum rather than just on Kenner's drawings. The first claim is that Kenner miscalculated the latitudes for which each network of lines on either side of the disc was drawn. The second claim is that Kenner misunderstood the letters inscribed on each side. Albèri-Auber believes that on one side Kenner was right to read RO, but wrong to think that these letters signify ROMA, when the network of lines here is now reckoned to be for about latitude 36 - which makes RODOS at this latitude seem much more likely (whereas Rome's correct latitude is six degrees further north, at 41 50) [Fig. 4]. On the other side, Albèri-Auber considers the network of lines to be drawn for a different latitude, but still one close to 36 . In consequence, he rejects Kenner's proposal of RAVENNA (correct latitude 44 20) for the letters RA here. Moreover, while not disputing the A read by Kenner, he maintains that there is no letter preceding it. Rather, only the single letter A was inscribed here, which he conjectures might signify (Syrian) ANTIOCHIA (correct latitude 3610 ), or possibly ATHENAE, given Strabo's report (Geog. 2.1.1) that Eratosthenes situated Rhodes and Athens on the same parallel [Fig. 5].

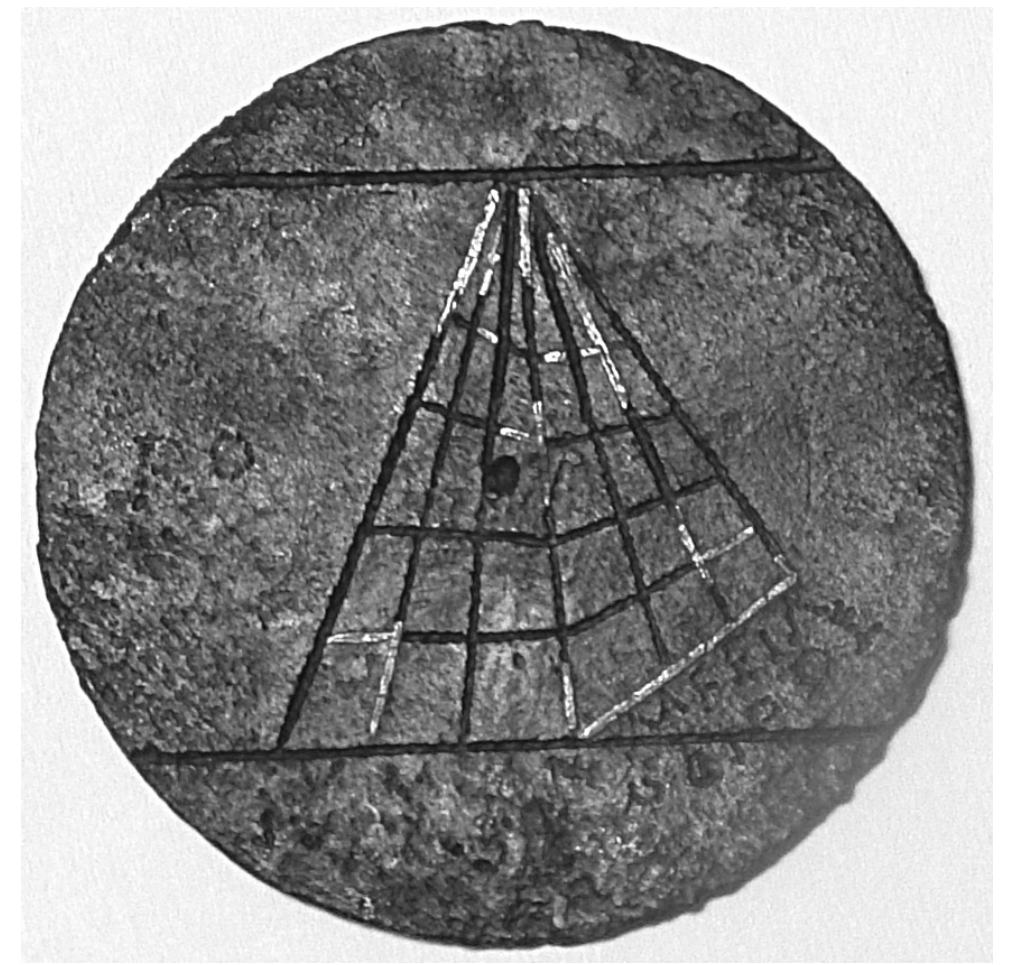

Fig. 4. "Aquileia" sundial disc, "RO" side, photograph courtesy of Civici Musei di Trieste, Italy. 


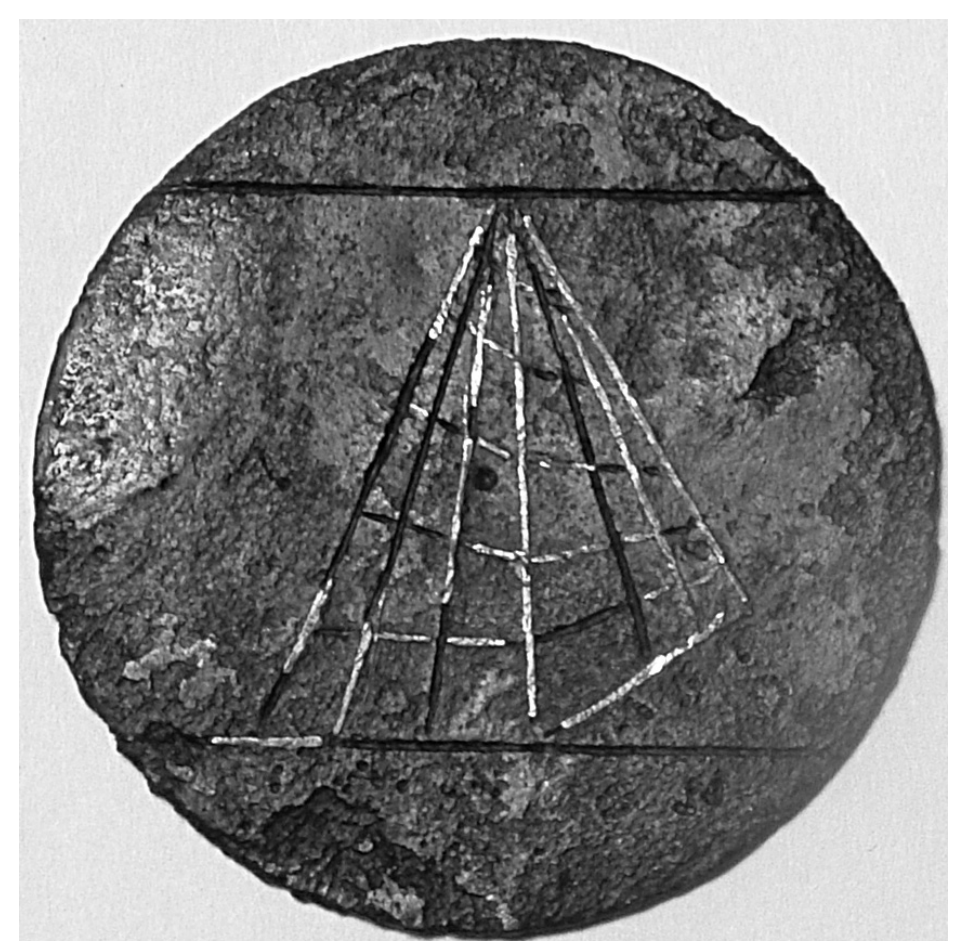

Fig. 5. "Aquileia" sundial disc, "[R]A" side, photograph courtesy of Civici Musei di Trieste, Italy.

Jones in his 2018 review (note 4) states independently that on the side with the letters RO the network of lines is for about latitude 36, and hence RODOS may well be meant. The network on the other side he reckons is for about latitude 38, so he now doubts the longstanding identification of RA as RAVENNA; but he stops short of proposing another location abbreviated as RA.

For my part, naturally I welcome the rediscovery of the disc, which I have yet to see for myself. Meantime I am intrigued by the reassessments of it put forward by Albèri-Auber and Jones. In reaction, let me state first that I see no cause to dispute their recalculation of the latitudes for which the network of lines on each side is drawn - both networks for about 36, they agree, or more specifically 36 and 38 in Jones' view. Equally, I accept the proposal made by both that RO on the latitude 36 side signifies RODOS. I would add the observation that the choice of this name for inclusion, while hardly a surprise, happens to be its first attested occurrence on any portable sundial inscribed in Latin ${ }^{7}$. This said, we may recall that RODO already occurs among the names inscribed in Latin on Side B of the marble fragment found at Aquincum (Budapest,

${ }^{7}$ Cf. Talbert 2017: 210 s.v. Rhodes. 
Hungary), which I have identified as a sundial maker's "manual". The inclusion of RODOS among the sundial's locations leaves no doubt that, while the intended user's language of choice was Latin, still the Greek East formed part of this person's worldview and geographical range.

The other side of the disc is self-evidently the source of greater difficulty. As a prefatory remark, even if on investigation I were to agree with Albèri-Auber that $\mathrm{A}$, and only $\mathrm{A}$, was inscribed here, I would still be puzzled by the presence of just a single letter. Abbreviation of a place- or region-name to as few as two letters has no match on any other portable sundial, whether inscribed in Greek or Latin, and even three letters is exceptional ${ }^{9}$. Abbreviation to a single letter does seem unlikely therefore (in particular when two letters are used on the other side), as well as needlessly unhelpful to a user. No doubt the "pillbox" sundial to which the disc belongs was custom-produced according to the specifications of a user familiar with the places chosen for inclusion. To that extent, for this private use merely minimal labeling might suffice. Even then, however, several names beginning with A (as many do in Latin !) certainly might be chosen, and it would be natural and easy to differentiate them with more than just a single letter ${ }^{10}$.

The Museum's photograph (Fig. 5) does at least demonstrate how Albèri-Auber might form the impression that $\mathrm{A}$ is the only letter inscribed on this side of the disc. Closer inspection of this side, however, together with the help of further photographs, raises competing concerns [Figs. 6, 7, 8]. At the outset it may be acknowledged that these photographs do enable us to understand how Kenner discerned a letter $\mathrm{R}$ before $\mathrm{A}$. This $\mathrm{R}$ was not merely a figment of his imagination therefore, but the photographs now raise the issue of how differently formed it is from the $\mathrm{R}$ of $\mathrm{RO}$ on the other side [Fig. 9]. In this latter instance the two lower strokes of the letter are not nearly so far apart. Indeed, the separation of those two strokes prompts me to question both whether what Kenner read as $\mathrm{R}$

\footnotetext{
${ }^{8}$ Talbert 2017: 198, with Figs. A.5, A.6. Albèri-Auber 2018: 13 concurs fully with this identification.

${ }^{9}$ Note GAL (with potential for confusion between Gallia and Galatia) and perhaps originally GER on the "Museum of the History of Science, Oxford" sundial, Talbert 2017: 54-57.

${ }^{10}$ How ROMA (if wanted on another disc) might be abbreviated distinctively in no more than two letters when RO signifies RODOS, I do not venture to speculate.
} 
before $\mathrm{A}$ is in fact $\mathrm{R}$, and whether this $\mathrm{A}$ in turn really is that letter rather than another.

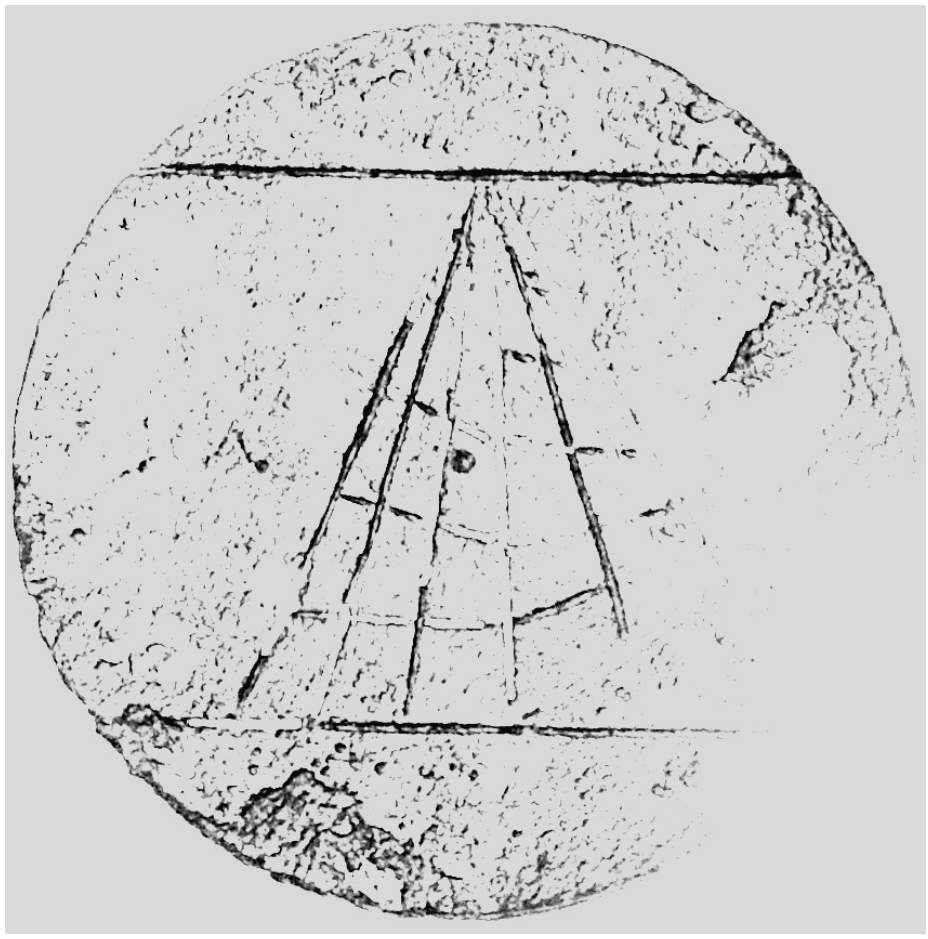

Fig. 6. "Aquileia" sundial disc, "[R]A" side, Fig. 5 above with image exposed to clarify details.

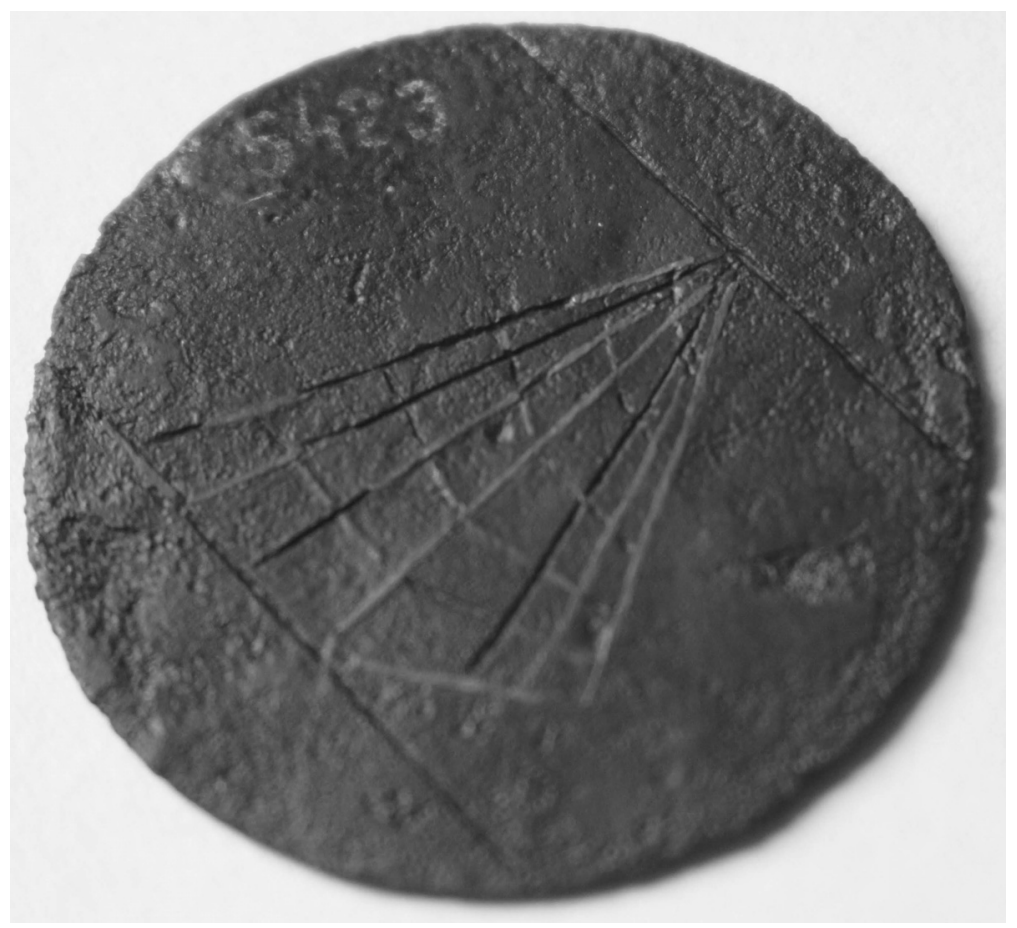

Fig. 7. "Aquileia" sundial disc, "[R]A" side, angled photograph by Caroline Kennedy and Olivia Zitkus, with the permission of Civici Musei di Trieste. 


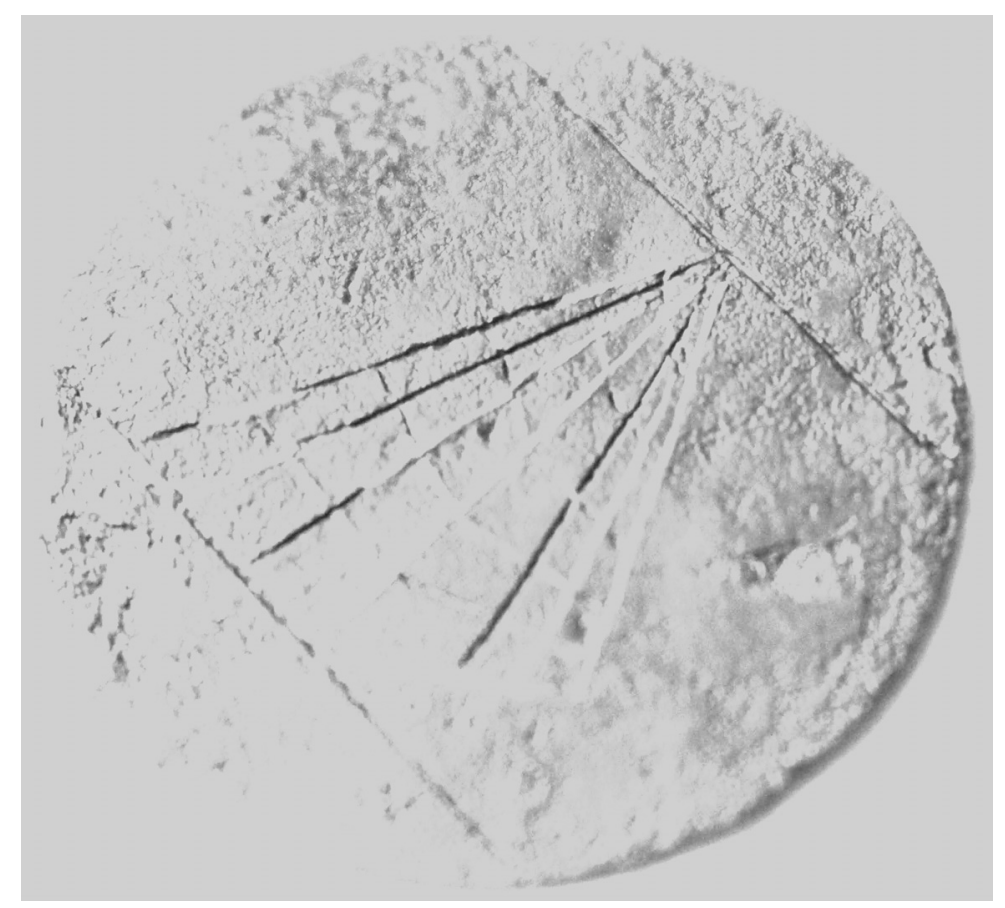

Fig. 8. "Aquileia" sundial disc, "[R]A" side, Fig. 7 above with image exposed to clarify details.

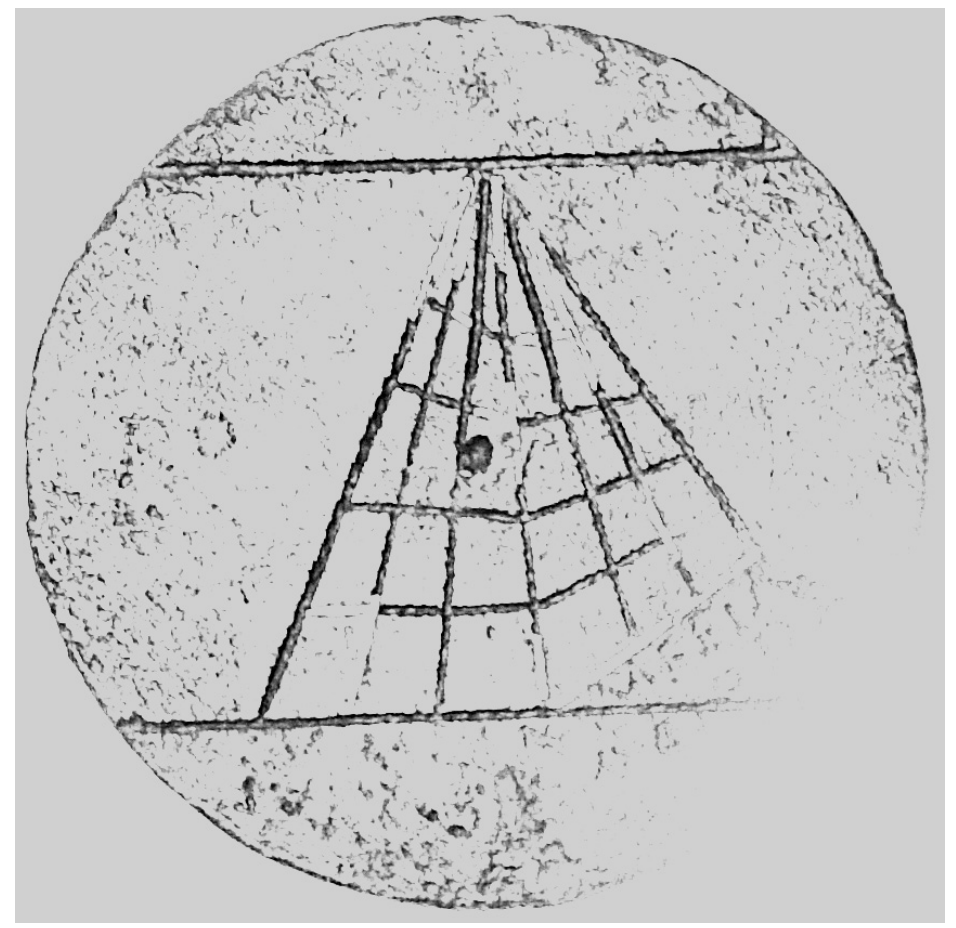

Fig. 9. "Aquileia" sundial disc, "RO" side, Fig. 4 above with image exposed to clarify details. 
In short, while I believe that there are two letters here (as on the other side) not just one, I have difficulty identifying either. Closer attention to how they are inscribed, and what can be discerned of each, is essential. They are evidently inscribed dot-by-dot rather than by line-work incisions, but the attempt to trace the courses created is thwarted by the intrusion of other, naturally-formed marks on the surface of the disc - a challenge to differentiate from inscribed dots. Random cuts and wear-and-tear add to the sense of confusion; such damage becomes extensive at the upper left. Here it seems that the disc's top surface has somehow been removed, a loss which (I suspect) may provide a basis for Albèri-Auber's claim that A was the only letter inscribed on this side. I present the result of a painstaking effort at the Ancient World Mapping Center to identify and trace nothing more than inscribed dots here: [Fig. 10]

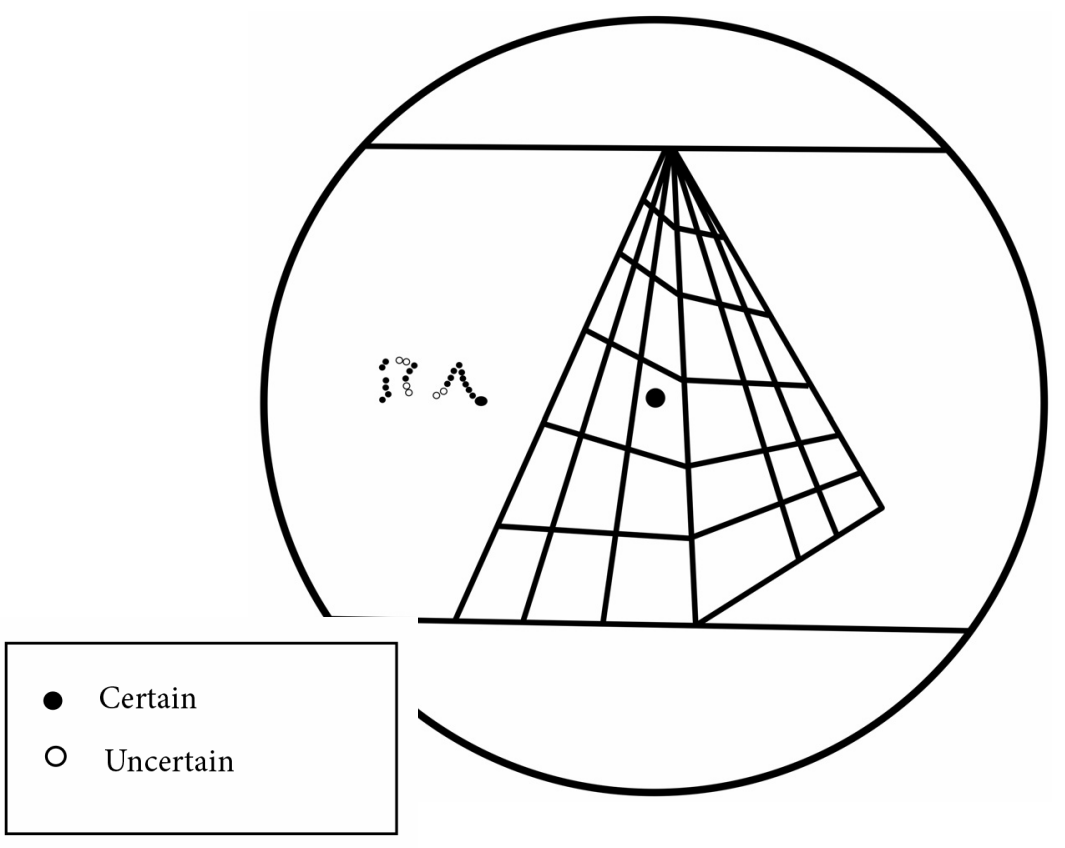

Fig. 10. "Aquileia" sundial disc, "[R]A" side, drawing of selected features from Figs. 5-8 above, Ancient Word Mapping Center.

It remains conceivable that the two rows of dots to the right form the letter A, even in the absence of a cross-bar ${ }^{11}$. However, I consider it more probable that these two rows and the one to the left of them are components of a letter $\mathrm{M}$ with its lefthand diagonal stroke now missing. Compare especially how $\mathrm{M}$ is written for the month May at bottom right below the network of lines (Fig. 5).

\footnotetext{
${ }^{11}$ For this variation in forming letter A on other portable sundials inscribed in Latin, see Talbert 2017: 54.
} 
I am very uncertain whether the left-hand upright stroke of the proposed $M$ really was connected to the vertical row of dots to its left. If the two "uncertain" dots with that possible function may be ignored, this vertical row must then form all or part of a separate letter. For it, I favor part of S, because SM - signifying SMYRNA - is such an attractive choice of major city around latitude 38 (correct latitude about 38 25). Its occurrence would in fact be the first on any portable sundial inscribed in either Latin or Greek, although Smyrna would have been a natural choice for inclusion on the (Greek) "Samos" sundial ${ }^{12}$. Nonetheless I at once admit that my identification of this first letter as $\mathrm{S}$ is largely wishful speculation, and I am also far from confident in identifying the second as $\mathrm{M}$. I maintain only that Kenner's reading RA, as well as Albèri-Auber's reading $\mathrm{A}$ as the single letter on this side, both call for reconsideration. I also consider SM(YRNA) a likely choice in principle for this side of the disc, if the network of lines here is drawn for around latitude 38 .

$$
* * *
$$

In the second part of this contribution I move to some broader consideration of timekeeping in Roman daily life. It is primarily my engagement with sundials and related devices which has aroused this interest ${ }^{13}$. By good fortune my perspective has been broadened by - among much else - the chapters in the volume published in 2016 to accompany the exhibition Time and Cosmos in GrecoRoman Antiquity ${ }^{14}$. Even so, for all the volume's merits, I find a challenge in the important question which the editor Alexander Jones poses in his Introduction and then, I think, answers incorrectly (28-29):

"Confronted as they were with time-keeping devices wherever they turned, we may wonder about the degree to which the ancient Greeks and Romans came to regulate their activities by the numbered hours. The testimony of the surviving Greek and Latin literature and of Greek documentary papyri .... suggests that, in private life, hours were seldom invoked; the conventional 'ninth hour' for dinner invitations ..... is perhaps the only important exception."

To be sure, Jones has in mind here the entire Greek and Roman world in space and time, from early Greece to the Late Roman

\footnotetext{
${ }_{13}^{12}$ Cf. my comment in Talbert 2017: 134.

${ }_{13}^{13}$ Note the collection at repository.edition-topoi.org/collection/BDSP.

${ }^{14}$ It appeared too late, however, to be taken into account for my own 2017 book.
} 
Empire. That may be too vast a span about which to generalize instructively, however. For present purposes, therefore, I intend to restrict my focus to Roman or Romanized communities from around the second century BCE to Late Antiquity - still an immense arena. For it at least, there is in plain sight plenty of testimony that Jones curiously chooses to overlook when he formulates his answer with reference - as he makes clear - just to literature and papyri.

This testimony is from inscriptions of one kind or another, written on stone or metal, or even on wax tablets. It is very scattered, and inevitably many items are only fragmentary survivals rather than complete documents. But I believe there is quite sufficient to justify the argument that for my arena Jones' claim is too restrictive. I also believe that with due awareness of this further testimony we should dare to re-think two long-held assumptions about Roman time consciousness in daily life: first, that any consciousness beyond the most rudimentary is found only among the educated elite and hardly extends down the social scale; second, that this level of consciousness is confined to urban environments, and thus absent in rural settings. The present contribution is no place to embark upon a lengthy refutation of these assumptions, but for brief illustration of how they may be brought into question I draw your attention first to one feature of an Italian city's daily life, and to one type of legal document defining an obligation that many ordinary folk incurred.

Puteoli, the major port in Campania, employed a contractor (manceps) who served as city-undertaker, with a slave work-gang under him. One section of a detailed notice - dating to the first century BCE - which he was obliged to post explains how residents could arrange for the removal of a corpse that they wanted to be rid of as soon as possible ( $A E$ 1971. 88 II lines 22-23). The hours referred to are of course the "flexible" twelve (varying in length according to season) into which Romans divided the day from sunrise to sunset:

"Suspendiosum cum denuntiat(um) erit ead horad is solvend(um) tollend(um) curato, item servom servamve si ante h(oram) $\mathrm{X}$ diei denuntiat(um) erit ead die tollend(um) curato, si post $\mathrm{X}$ poster(a) d(ie) a(nte) h(oram) II."

"Should instructions be given [to remove] a hanged man, he (the contractor) is to see to their fulfilment and the removal within the hour. In the case of a male or female slave, if instructions be given before the tenth hour of the day, removal is to be effected that day; if after the tenth, on the next day before the second hour." 
An obligation on the part of a free person to report to a specified place, with day and time also specified, occurs very notably in the context of legal proceedings. Such obligations are well documented in first-century CE wax tablets unearthed in the area of Pompeii. The most common type of document, a vadimonium (in modern terms, a bail-bond), is a promise made by the defendant in a private dispute to appear at a particular place at a stated hour on a specific date for the hearing of the dispute or its continuation. This undertaking could be entered into voluntarily by the parties involved; or it could be required by a judge, in Italy especially in instances where the case was beyond the competence of a local court and so had to be transferred to the praetor's court in Rome. The defendant's promise is accompanied by an undertaking to pay the plaintiff a specified sum of money in the event of failure to appear, as in this typical example from the mid $70 \mathrm{~s}^{15}$ :

"Vadimonium factum Cala

toriae Themidi in iii Non(as)

Decemb(res) prim(as) [vacat $]$

$\mathrm{R}[\mathrm{o}] \mathrm{mae}$ in foro Augus(to) ante

tribunal praetoris urbani

hora secun[d]a HS M dari

stipulata es[t] ea q[uae] se

Petroniam [Sp. f. Iustam]

esse dicat, $\mathrm{s}[\mathrm{po}] \mathrm{po}[\mathrm{ndit}]$

Calatoria [Them]is t(utore) a(uctore) $\mathrm{C}$.

Petronio Tel[e]sph[o]ro.

V.f. [C. Petronio Telesphoro].”

"A vadimonium was made against Calatoria Themis for December $3^{\text {rd }}$ in Rome in the Forum of Augustus before the tribunal of the urban praetor at the second hour. The woman who calls herself Petronia Iusta, daughter of [name lost], stipulated for, and Calatoria Themis, on the authority of her 'guardian' C. Petronius Telesphorus, answered for, the payment of 1,000 sesterces."

Regardless of whether such undertakings are made for Rome or elsewhere, the third hour is usually specified, but the first, second (as in this instance), fourth, fifth, and even ninth hour are all $\operatorname{attested}^{16}$. It emerges from literary sources that a long court day

${ }^{15}$ Tabulae Herculanenses 14, as quoted and translated by Bablitz 2007: $17-18$.

${ }^{16}$ Bablitz 2007: 182 with nn. 89-90; for specified times, see further Laurence 2007: 154-166. 
could stretch from the third hour to the tenth (Bablitz 2007: 184). Needless to add, for ordinary folk 1,000 sesterces would be a painful amount to forfeit, should they fail to appear as promised; by comparison, at this period 900 was a year's basic pay for a Roman legionary.

As one means of calling into question the second assumption that the time consciousness found in urban environments is absent in rural settings - I draw to your attention a type of inscribed document which amply demonstrates otherwise. These are notices stating which owners in an area can irrigate their land with water from a nearby spring or aqueduct, on which day, between which hours and even half-hours. Predictably enough, disputes over access to such water sources would have occurred all too readily, and the authorities must always have been concerned to secure agreement among owners.

Inevitably, detailed documentation of such agreements seldom survives. The fullest such surviving example is from Lamasba in Numidia, not far north-west of Timgad (in modern Algeria) (Barrington Atlas 34 D2). It comprises four fragments of a large stone on which is inscribed a decree issued by the municipality during the reign of Elagabalus (218-222 CE); from these fragments, however, it impossible to determine the original full size of the inscription (CIL VIII. 18584). More than eighty of the decree's entries are preserved. Each specifies the following in a highly abbreviated format: name of the owner; size of his property; times of day from which, and to which, the property may be watered; total duration of this period for watering. The following entry quoted and translated by Brent Shaw is typical: [Fig. 11]

\begin{tabular}{|c|c|}
\hline \multirow[t]{2}{*}{ MATTIVS FORTIS } & \multirow{2}{*}{$\begin{array}{cc}\text { K CCCVIII } & \text { EX H*I* } \text { H }^{*} \mathrm{VIII}^{*} \mathrm{KAL}^{*} \text { OCTOBR } \\
\text { IN } \mathrm{H} & \mathrm{VS}^{*} \mathrm{D}^{*} \text { EIUSDEM P P S H IIIIS }\end{array}$} \\
\hline & \\
\hline Name of proprietor & Mattius Fortis \\
\hline Size of property : & 308 K(apita) \\
\hline Time period: & $\begin{array}{l}\text { ex h(ora) ( (prima) d(iei) (septimi) kal(endas) } \\
\text { octobr(es) in h(oram) (quintum dimidiam) } \\
\text { d(iei) eiusdem. }\end{array}$ \\
\hline \multirow[t]{2}{*}{ Total time : } & p(ro) p(arte) s(ua) h(orae) (quattuor et) s(emis) \\
\hline & (i.e.. for his plot. a total of 4.5 hours)* \\
\hline
\end{tabular}

Fig. 11. Entry (adapted) from CIL VIII.18584, as quoted and translated by Shaw 1982: 71. 
This owner (proprietor), Mattius Fortis, is authorized to water his 308 kapita from the first hour of the day on September $25^{\text {th }}$ to the fifth-and-a-half hour of the same day, a period of 4.5 hours ${ }^{17}$. Note that here "from the first hour of the day" signifies "from the end of the first of the day's twelve hours," not from the beginning of this hour, which is dawn (prima lux). The date specified (September $25^{\text {th }}$ ) is no doubt meant as the fall equinox, marking when this schedule is to begin.

To return to Jones' answer quoted above, I consider it too restrictive when he suggests that "in private life, hours were seldom invoked." On the contrary, my sense is rather the opposite, namely that among Romans at least there was a marked preoccupation with the hours in both urban and rural environments. Indeed, I gain the impression that the level of time consciousness in Roman daily life is clearly higher than that found in any other society of classical antiquity, Egypt or the Near East. To be sure, in saying this I in no way mean to deny or devalue the invention of hours and the attention paid to them in these other societies (further large topics which cannot be explored here); but nowhere among them, it seems, does such consciousness become as widespread and influential as it does among Romans ${ }^{18}$. To the best of my knowledge, that higher level still awaits adequate recognition as a formative feature of the Roman community and its mindset, one that spreads throughout the empire as its territory expands ${ }^{19}$.

Moreover, Roman preoccupation with hours has evidently been overlooked as a forerunner to the emergence of comparable time consciousness in early modern Europe. In the Introduction (11) to her 2015 study The Global Transformation of Time 1870-1950, Vanessa Ogle endorses the proposition by Jacques Le Goff that:

“ .... the emergence of a commercial market society in fourteenth- and fifteenth-century Europe was accompanied by a growing utility for marking time, hence the proliferation of work bells, tower clocks, and other visible and audible signals denoting various times. Ever since, the emergence of capitalist society has been closely tied to the proliferation of clocks and the honing of time consciousness." (See further Le Goff 1980).

${ }^{17}$ Shaw errs in understanding the period here to be during the afternoon; rather, it is during the morning, with its end 1.5 hours before midday (which occurs at the end of the sixth hour).

${ }^{18}$ See, for example, Englund 1988; Spalinger 1996; Kadish 2001; Symons, Khurana 2016.

${ }_{19}$ In his Conclusion Bonnin 2015: 353 singles out this feature, but elaborates no further. 
Needless to say, the raised level of time consciousness in Roman daily life did not lead to economic and social changes that match those experienced later in early modern Europe. Even so, the question of what changes in Roman society may have been caused or accelerated still merits consideration. More fundamentally, attention should be given to the equally large issues of how, why and when the Roman community raised its level of time consciousness, a development which certainly began well before the end of the Republic ${ }^{20}$; also, centuries later, why and when that level was no longer maintained. In this contribution a call for such inquiries on the grand scale does indeed represent a great leap from the microhistorical reassessment of a lost sundial disc now found again. But even this one tiny object reflects a distinctively close Roman engagement with time and space that scholars are only now beginning to penetrate with fresh eyes ${ }^{21}$.

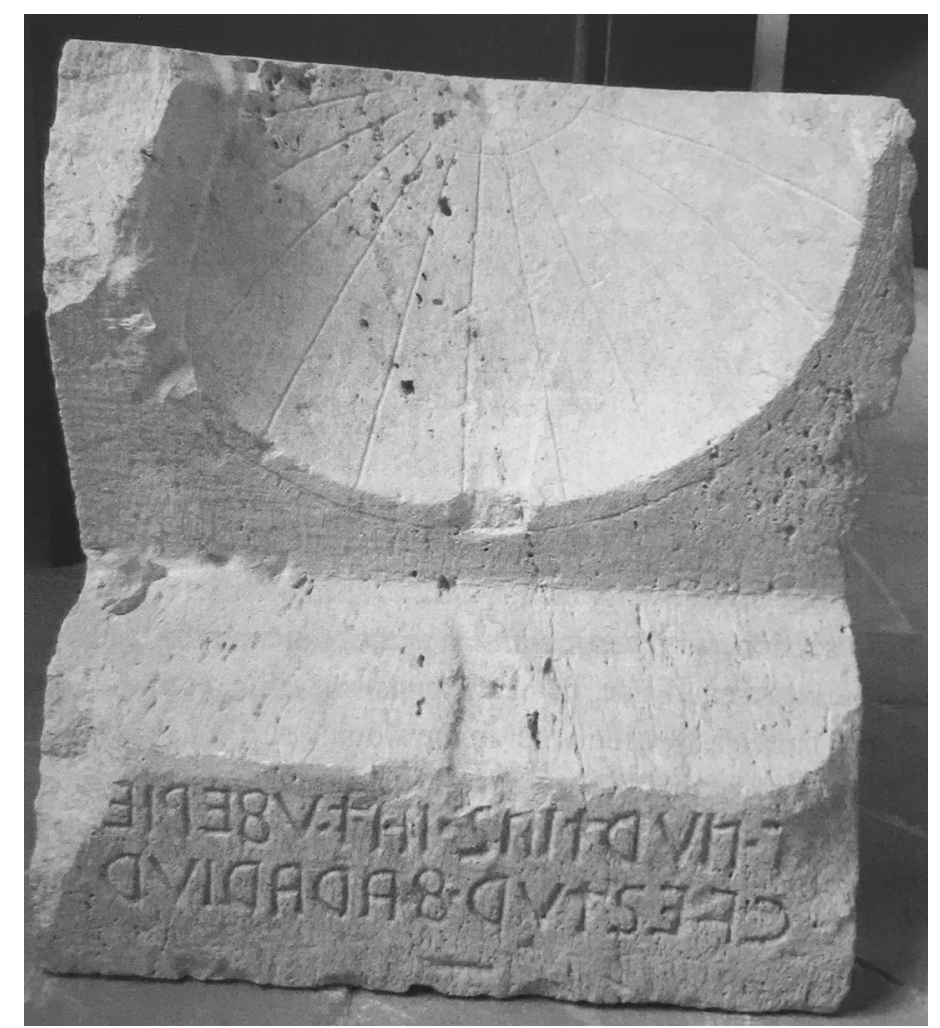

Fig. 12. Sundial unearthed by ploughing outside Mevania (Umbria), 1969. Erected c. $100 \mathrm{BCE}$; inscription in Umbrian alphabet. Imagines Italicae vol. 1 p. 122.

\footnotetext{
${ }^{20}$ The question arises of how far Italic peoples influenced Rome in this respect, or Rome them: note the fixed sundials erected publicly at Mevania (Umbria) and Interamna Lirenas (Latium) [Figs. 12, 13].

${ }_{21}$ Among related recent initiatives, note Ben-Dov, Doering (eds.) 2017; Miller, Symons (eds.) (Forthcoming).
} 


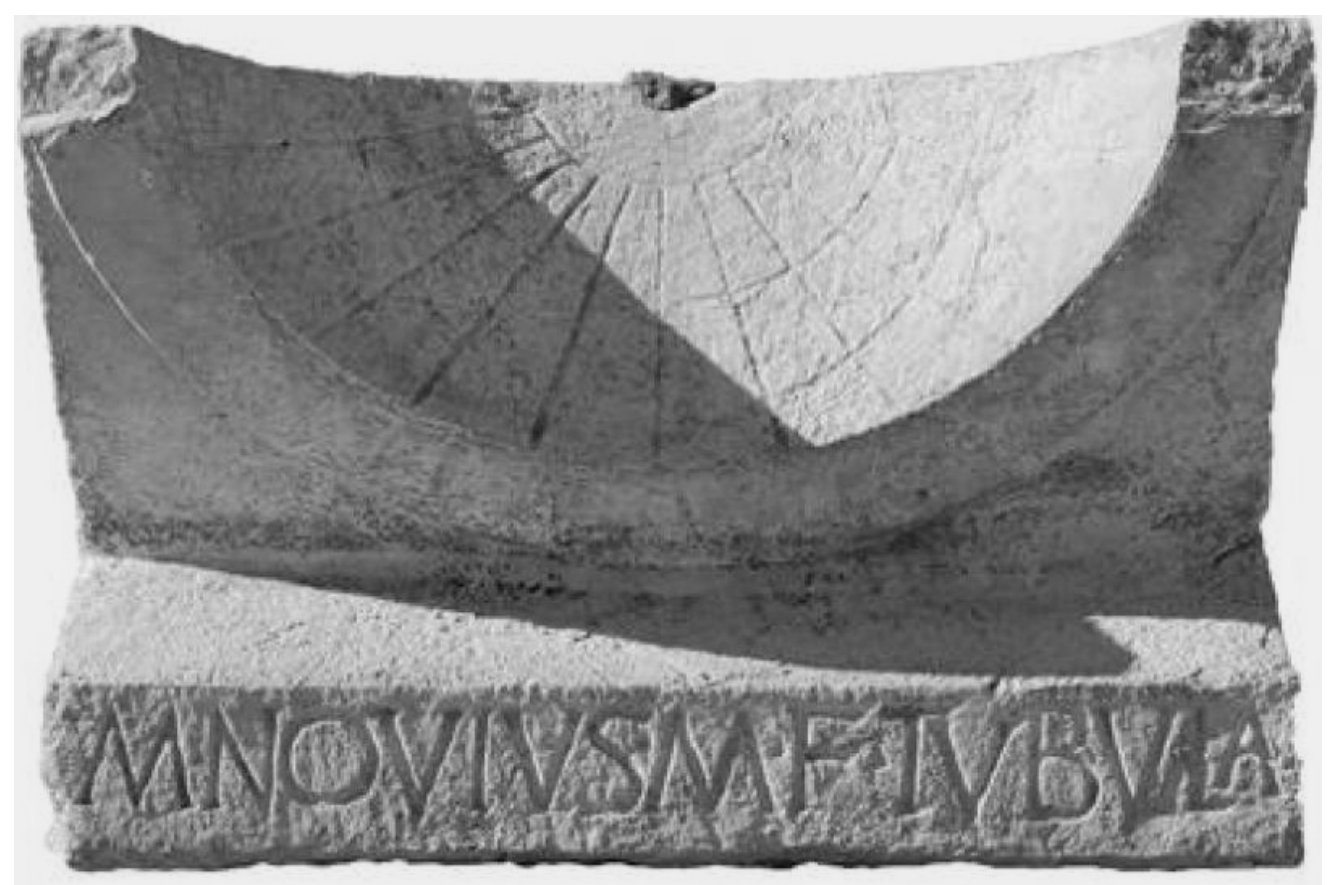

Fig. 13. Sundial excavated at Interamna Lirenas (Latium), 2017. Erected mid-first century BCE. Photograph by Alessandro Launaro, courtesy of Faculty of Classics, University of Cambridge, Soprintendenza Archeologia Belle Arti e Paesaggio per le Province di Frosinone, Latina e Rieti, and Comune di Pignataro Interamna (www.classics.cam.ac.uk/interamna).

\section{Bibliography}

Albèri-Auber, P. 2005: Un orologio solare portatile da Aquileia romana: il 'tondello' RO-A. Gnomonica Italiana 9 (November): 8-13.

Albèri-Auber, P. 2018: The Aquincum fragment. The Compendium 25.2: $13-24$.

Bablitz, L. 2007: Actors and Audience in the Roman Courtroom. London and New York: Routledge.

Ben-Dov, J., Doering, L. (eds.). 2017: The Construction of Time in Antiquity: Ritual, Art, and Identity. Cambridge: Cambridge University Press.

Bonnin, J. 2015: La mesure du temps dans l'Antiquité. Paris: Les Belles Lettres.

Englund, R. K. 1988: Administrative timekeeping in ancient Mesopotamia. Journal of the Economic and Social History of the Orient 31: 121185.

Jones, A. (ed.). 2016: Time and Cosmos in Greco-Roman Antiquity. Princeton: Princeton University Press.

Jones, A. 2018: Review of Talbert 2017. Classical Philology 113.2: 232237.

Kadish, G. E. 2001: Time. In: Redford, D. B. (ed.). The Oxford Encyclopedia of Ancient Egypt. Vol. 3. Oxford: Oxford University Press: 405-409. 
Laurence, R. 2007: Roman Pompeii: Space and Society. Ed. 2. London and New York: Routledge.

Le Goff, J. 1980: Merchant's time and church's time in the Middle Ages. In: J. Le Goff (trans. Arthur Goldhammer), Time, Work, \& Culture in the Middle Ages, 29-42. Chicago and London: University of Chicago Press (originally published in French, 1960).

Miller, K., Symons, S. (eds.). (Forthcoming). Down to the Hour: Perspectives on Short Time in the Ancient Mediterranean. Leiden: Brill. [2017 conference proceedings, https://humanities.uchicago. edu/calendar/details/CAL-ff808081-5a64cbd9-015a-661b2ef800001312eventscalendar\%2540uchicago.edu]

Ogle, V. 2015: The Global Transformation of Time 1870-1950. Cambridge, MA, and London: Harvard University Press.

Shaw, B. D. 1982: Lamasba: An ancient irrigation community. Antiquités Africaines 18: 61-103.

Spalinger, A. 1996 : Some times. Revue d'Egyptologie 47: 67-77.

Symons, S., Khurana, H. 2016: A catalogue of ancient Egyptian sundials. Journal for the History of Astronomy 47.4: 375-385.

Talbert, R. J. A. 2017: Roman Portable Sundials: The Empire in Your Hand. Oxford: Oxford University Press. 